\title{
ANALISIS PEMBOROSAN MENGGUNAKAN "9 WASTE" PADA PROSES PRODUKSI PT ABC
}

\author{
Ikhsan Baharudin ${ }^{1}$, Ahmad Jaka Purwanto ${ }^{2}$, Muchammad Fauzi ${ }^{3}$ \\ Program Studi Teknik Industri, Fakultas Teknik ${ }^{1,2,3}$ \\ Universitas Widyatama \\ Jl. Cikutra No. 204 A, Bandung \\ ikhsan.baharudin@widyatama.ac.id ${ }^{1}$, ahmad.jaka@widyatama.ac.id ${ }^{2}$, muchammad.fauzi@widyatama.ac.id ${ }^{3}$
}

\begin{abstract}
Abstrak
Sistem produksi yang efektif dan efisien akan menghasilkan produk yang berkualitas, sehingga perusahaan tidak mengalami kerugian. Kerugian yang dialami suatu perusahaan salah satunya karena permasalahan pemborosan (waste). Pada penelitian ini bertujuan untuk menganalisis waste pada produksi produk X di PT ABC menggunakan pendekatan Lean. Hasil klasifikasi menunjukkan bahwa keseluruhan aktivitas produksi dari setiap proses yang didapat adalah sebesar $22 \%$ untuk value-added activity (VA), $22 \%$ untuk non value-added activity (NVA), dan 56\% untuk necessary non value-added activity (NNVA). Dari hasil klasifikasi tersebut kemudian dapat diidentifikasi dalam 9 faktor yang dapat menyebabkan waste. 9 Waste tersebut disingkat dengan $E$ Downtime, yang terdiri dari Environmental, Health, and Safety (EHS), Defect, Over Production, Waiting, Non-Utilizing Employee, Transportation, Inventory, Motion, dan Excess Proceessing. Berdasarkan hasil identifikasi dan analisa, permasalahan waste yang terjadi adalah setiap proses operasi selesai, benda trial untuk produk $\mathrm{X}$ akan dilakukan pengukuran oleh tim $Q A$, dan pengukuran tersebut dilakukan terus berulang hingga operasi terakhir. Selain itu, terdapat antrian dari tim $Q A$ sehingga menimbulkan downtime yang cukup lama, akibatnya lead time produksi akan lebih lama. Usulan perbaikan yang direkomendasikan oleh peneliti adalah supaya pengukuran benda trial oleh tim $Q A$ dilakukan secara sekaligus yaitu satu kali setelah proses produksi dari operasi pertama sampai operasi terakhir telah selesai. Hal tersebut dapat meminimalkan waktu menganggur operator produksi sehingga mampu menghilangkan waste di PT ABC.
\end{abstract}

Kata kunci :

Produksi, Pemborosan, Lean

\begin{abstract}
An effective and efficient production system will produce quality products, so the company does not experience losses. One of the losses experienced by a company is due to waste problems. This study aims to analyze the waste in the production of product $X$ at $P T A B C$ using the Lean approach. The classification results show that the overall production activity of each process obtained is $22 \%$ for value-added activities (VA), 22\% for non-value-added activities (NVA), and $56 \%$ for required non-value-added activities (NNVA). From the results of the classification can then be identified in 9 factors that can cause waste. 9 Waste is abbreviated as EDowntime, which is from Environmental, Health, and Safety (EHS), Defect, Over Production, Waiting, NonUtilizing Employee, Transportation, Inventory, Motion, and Excess Processing. Based on the results of identification and analysis, the waste problem that occurs is that each operation process is completed, the trial object for product $X$ will be measured by the $Q A$, and the measurement is carried out repeatedly until the last operation. In addition, there is a queue from the $Q A$ side, causing quite a long downtime, as a result the production lead time will be longer. The proposed improvement recommended by the researcher is that the measurement of trial objects by the QA party is carried out simultaneously, namely once after the production process from the first operation to the last operation has been completed. This can minimize the production operator's idle time so as to eliminate waste at PT ABC.
\end{abstract}

Keywords :

Production, Waste, Lean

Ikhsan Baharudin, Ahmad Jaka Purwanto, Muchammad Fauzi 


\section{Pendahuluan}

Proses produksi merupakan kegiatan paling penting dalam sebuah industri, proses tersebut sangat mempengaruhi naik atau turunnya perusahaan dalam melayani konsumen. Hal ini karena proses produksi menambahkan nilai guna suatu benda atau menciptakan benda baru sehingga lebih bermanfaat untuk memenuhi kebutuhan. Kegiatan menambah nilai guna suatu benda tanpa mengubah bentuknya disebut dengan jasa. Sedangkan kegiatan menambah daya guna suatu benda dengan mengubah sifat dan bentuknya disebut produksi barang. Sistem produksi yang efektif dan efisien mampu menghasilkan produk yang berkualitas, sehingga perusahaan tidak mengalami kerugian. Kerugian yang dialami suatu perusahaan salah satunya karena permasalahan pemborosan (waste). Waste merupakan suatu kerugian berbagai sumber daya seperti material, waktu dan juga modal yang disebabkan oleh kegiatan yang tidak menambah nilai kepada produk akhir.

PT ABC adalah perusahaan yang bergerak dibidang manufaktur yang memproduksi part-part presisi dengan menggunakan mesin Computer Numerical Control (CNC). Berdasarkan hasil observasi dalam studi lapangan yang telah dilakukan, diperoleh permasalahan waste pada proses produksi untuk produk $\mathrm{X}$ seperti banyaknya waktu menganggur operator dan terdapat produk defect. Dampak dari permasalahan waste tersebut adalah downtime selama 30 menit di setiap operasi dan menyebabkan bertambahnya lead time produksi sehingga terjadi keterlambatan pengiriman selama 2 hari. Perbaikan untuk permasalahan tesebut perlu dilakukan supaya meningkatkan efektifitas dan efisiensi produksi di PT ABC. Maka dari itu penelitian ini bertujuan untuk menganalisis waste pada proses produksi produk $\mathrm{X}$ tersebut menggunakan pendekatan Lean Manufacturing, dimana dalam konsep Lean Manufacturing terdapat 9 faktor penyebab waste pada industri manufaktur yang disingkat dengan $E$ Downtime.

\section{LANDASAN TEORI}

Lean Manufacturing merupakan upaya perbaikan yang dilakukan terus menerus pada industri manufaktur untuk menghilangkan pemborosan (waste) dan meningkatkan nilai tambah pada barang atau jasa. Lean berfokus pada identifikasi dan eliminasi aktivitas yang tidak bernilai tambah dalam desain produksi (untuk bidang manufaktur) atau operasi (untuk bidang jasa) dan supply chain management (Gaspersz, 2007). Waste didefinisikan sebagai segala aktivitas kerja yang tidak memberikan nilai tambah dalam proses transformasi input menjadi output sepanjang value stream (proses memproduksi, mendistribusikan produk baik barang atau jasa ke pasar (Novitasari \& Iftadi, 2020). Maka dari itu waste harus diminimalkan atau dihilangkan karena berdampak menurunkan produktivitas dan profit bagi perusahaan.

\section{II.1 Prinsip Dasar Lean}

Terdapat lima prinsip dasar pada Lean (Soenaryo et al., 2015), sebagai berikut:

1. Mengidentifikasi nilai produk berdasarkan perspektif pelanggan, dimana pelanggan menginginkan produk berkualitas superior, dengan harga yang kompetitif dan penyerahan tepat waktu.

2. Mengidentifikasi proses aliran value untuk setiap produk.

3. Menghilangkan pemborosan yang tidak bernilai tambah dari semua aktivitas sepanjang proses aliran value.

4. Mengorganisasikan agar material, informasi, dan produk itu mengalir secara lancar dan efisien sepanjang proses aliran value menggunakan sistem tarik (pull system).

5. Terus menerus mencapai berbagai teknik dan alat pengembangan (improvement tools) untuk mencapai keunggulan dan peningkatan terus menerus.

\section{II.2 Jenis Value Activity}

Dalam suatu organisasi terdapat jenis-jenis aktivitas yang terjadi (Hines, 2000), sebagai berikut:

1. Value - Added Activity (VA), yaitu aktivitas dalam proses produksi yang memberikan nilai tambah pada suatu produk atau jasa.

2. Non Value - Added Activity (NVA), yaitu aktivitas yang tidak memberikan nilai tambah apapun pada suatu produk atau jasa selama proses produksi.

3. Necessary But Non Value - Added Activity (NNVA), yaitu aktivitas yang tidak ada penambahan nilai tambah produk atau jasa tetapi proses yang dilakukan masih tetap diperlukan.

Ikhsan Baharudin, Ahmad Jaka Purwanto, Muchammad Fauzi 


\section{II.3 Jenis Pemborosan (Waste)}

Menurut Gaspersz (2006), pada Lean Manufacturing terdapat 9 jenis faktor pemborosan (waste) yang disingkat E-Downtime, Berikut merupakan penjelasan dari masing-masing waste tersebut:

\section{Environtmental Health, and Safety (EHS)}

Jenis pemborosan yang terjadi karena kelalaian dala memperhatikan hal-hal yag berkaitan dengan prinsip EHS (Gaspersz V., 2006).

2. Defect

Jenis pemborosan yang terjadi karena munculnya produk cacat. Defect selalu terlihat pada industri manufakur karena berhubungan langsung dengan biaya perusahaan (Aziza \& Afandi, 2018).

\section{Over Production}

Jenis pemborosan yang disebabkan produksi yang berlebihan. Kategori tersebut dimana produk yang dihasilkan melebihi dari yang direncanakan di awal (Pattiapon et al., 2020).

4. Waiting

Jenis pemborosan yang terjadi karena suuatu proses yang terhambat sehingga proses selanjutnya harus menunggu proses sebelumnya menyelesaikan pekerjaannya (Puspa S. et al., 2017).

\section{Non-Utilizing Employee}

Jenis pemborosan sumber daya manusia yang terjadi karena karyawan sebagai sumber daya tidak mampu melakukan pekerjaannya secara optimal disebabkan kurangnya kompetensi (Gaspersz V. , 2006).

6. Transportation

Kegiatan transportasi yang berlebihan akan menyebabkan terbuangnya biaya, waktu, dan tenaga (Jakfar \& Setiawan, 2014).

7. Inventory

Jenis pemborosan yang terjadi karena diperlukannya bahan baku produksi pada inventory yang berlebihan. Konsep Just In Time diperlukan untuk menghilangkan pemborosan yang ada (Janson B \& Nurcaya, 2019).

\section{Motion}

Jenis pemborosan yang terjadi karena pergerakan yang tidak perlu oleh operator dan dapat memperlambat proses sehingga leadtime menjadi lebih lama (Havi et al., 2018).

\section{Excess Processing}

Jenispemborosan yang terjadi karena diperlukannya tahapan dalam proses yang berlebihan. Pada kategori ini meliputi proses yang tidak perlu seperti pengerjaan ulang (Gaspersz V., 2006).

\section{ANALISIS DAN PEMBAHASAN}

Langkah awal dalam penelitian ini adalah dengan mengetahui aktivitas untuk proses produksi produk X. Produk $\mathrm{X}$ diproses dengan 8 operasi menggunakan mesin $C N C 3$ Axis dan 1 operasi menggunakan mesin Survace Grinding. Setiap operasi dibuatkan benda trial sebagai bentuk sampel untuk dilakukan pengukuran oleh tim $Q A$ yang bertujuan untuk memastikan bahwa dimensi sesuai dengan permintaan costumer. Setelah benda trial dinyatakan lulus pengukuran oleh tim $Q A$, proses operasi selanjutnya untuk produk tersebut baru akan dilakukan. Cycle time pada setiap operasi ditunjukkan pada Tabel 1 sebagai berikut:

Tabel 1. Cycle Time

\begin{tabular}{clcc}
\hline $\begin{array}{c}\text { No. } \\
\text { Operasi }\end{array}$ & Mesin & $\begin{array}{c}\text { Set Up } \\
\text { Time } \\
\text { (Menit) }\end{array}$ & $\begin{array}{c}\text { Cycle } \\
\text { Time } \\
\text { (Menit) }\end{array}$ \\
\hline \hline 20 & Milling 3 Axis & 2,5 & 15 \\
30 & Surface & 1 & 40 \\
& Grinding & 3 & 90 \\
35 & Milling 3 Axis & 2 & 60 \\
40 & Milling 3 Axis & 2,5 & 60 \\
45 & Milling 3 Axis & 2,5 \\
50 & Milling 3 Axis & 2 & 60 \\
55 & Milling 3 Axis & 2 & 40 \\
60 & Milling 3 Axis & 1,5 & 15 \\
65 & Milling 3 Axis & 2 & 45 \\
& Bench Work & & 10 \\
& Inspection & & 40 \\
\hline \hline
\end{tabular}

Daftar aktivitas pada setiap proses operasinya adalah sama, dimulai dari persiapan alat potong ke

Ikhsan Baharudin, Ahmad Jaka Purwanto, Muchammad Fauzi 
bagian tool management, proses pengerjaan di mesin, sampai dilakukan pengukuran oleh tim $Q A$. Daftar aktivitas ditunjukkan pada Tabel 2 sebagai berikut:

Tabel 2. Daftar Aktivitas

\begin{tabular}{lccc}
\hline \hline \multicolumn{1}{c}{ Activity } & & & \\
\multicolumn{1}{c}{ Classification } & VA & NVA & NNVA \\
\hline \hline $\begin{array}{l}\text { Melakukan persiapan } \\
\text { alat potong }\end{array}$ & & & $\checkmark$ \\
$\begin{array}{l}\text { Melakukan set up } \\
\text { mesin }\end{array}$ & & & $\checkmark$ \\
$\begin{array}{l}\text { Melakukan set up alat } \\
\text { potong }\end{array}$ & & & \\
$\begin{array}{l}\text { Membuat main } \\
\text { program di mesin }\end{array}$ & & & $\checkmark$ \\
$\begin{array}{l}\text { Menjalankan program } \\
\text { Operator menunggu } \\
\text { dan mengawasi }\end{array}$ & $\checkmark$ & & $\checkmark$ \\
jalannya program & & & \\
$\begin{array}{l}\text { Pengecekan dimensi } \\
\text { dan visual benda }\end{array}$ & & $\checkmark$ & \\
$\begin{array}{l}\text { Melakukan proses } \\
\text { Bench Work } \\
\text { Pengukuran oleh } Q A\end{array}$ & & $\checkmark$ & \\
\hline \hline
\end{tabular}

Berdasarkan Tabel 2 diatas, keseluruhan aktivitas produksi dari setiap proses yang didapat adalah sebesar $22 \%$ untuk value-added activity (VA), 22\% untuk non value-added activity (NVA), dan $56 \%$ untuk necessary non value-added activity (NNVA), seperti pada Gambar 1 berikut ini:

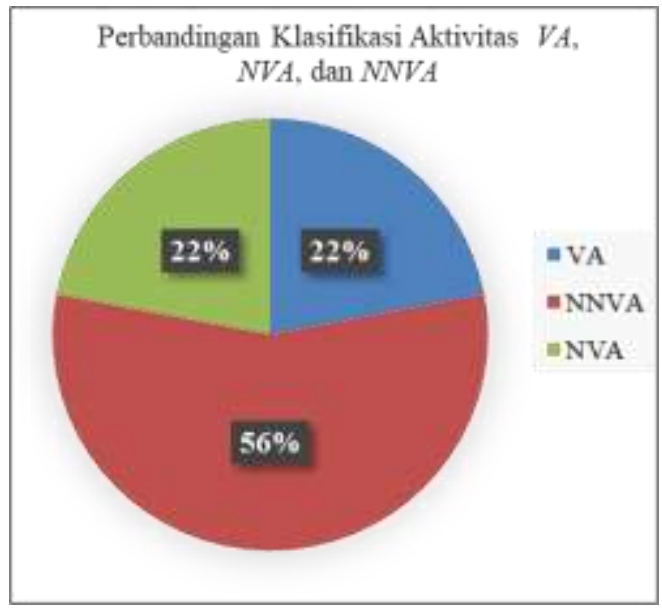

Gambar 1 Perbandingan Klasifikasi Aktivitas VA, $N V A$, dan $N N V A$
Setelah mengklasifikasikan aktivitas tersebut kemudian dapat diidentifikasi dalam 9 faktor penyebab waste pada produk $\mathrm{X}$, sebagai berikut:

\section{Faktor Environtmental Health, and Safety (EHS)}

Pada Production Area PT ABC tidak ditemukan permasalahan mengenai waste EHS karena lingkungan kerja yang cukup baik dengan suhu antara $26-27^{\circ} \mathrm{C}$. Pada suhu tersebut lingkungan kerja terasa sedikit panas namun masih dalam batas kewajaran. Selain itu disediakan pula fasilitas-fasilitas untuk menurunkan suhu ruangan seperti kipas angin blower, ventilasi, jendela, dan pintu masuk yang berukuran besar sehingga lebih memudahkan udara luar untuk bersikulasi dalam area produksi. Dari segi operator pun sudah cukup baik. Hal ini dapat diketahui dari operator yang sudah menggunakan Alat Perlindungan Diri (APD) yang sudah sesuai dengan SOP seperti mengenakan masker, sarung tangan, dan safety shoes.

\section{Faktor Defect}

Pada keseluruhan proses, terjadi defect sebanyak 1 unit pada operasi 50 dimana adanya kekeliruan setup oleh operator. Setup alat potong yang seharusnya menggunakan centerdrill diameter 3, tetapi operator memasang alat potong dengan diameter 6. Hal ini menyebabkan adanya damaged pada bagian dinding radius. Sehingga produk tersebut tidak dapat digunakan dan harus diganti dengan material baru dan dilakukan proses dari awal kembali. Kesalahan ini akibat disetiap produk akan di proses harus dilakukan setup secara manual.

\section{Faktor Over Production}

Dari hasil pengamatan dan brainstorming pada area produksi, over production merupakan salah satu waste yang sering terjadi di proses produksi. Waste ini disebabkan karena adanya kesalahan komunikasi antar operator dan kesalahan pengoperasian mesin produksi yang tidak sesuai dengan spesifikasi yang diharapkan. waste over production ini sendiri terjadi karena efek domino dari waste kategori defect. Beberapa terjadi karena kesalahan operator dalam membaca atau melakukan input pada mesin produksi. Adanya produk yang defect menyebabkan terjadinya waste over production. Adanya waste over production pada produk $\mathrm{X}$ adalah karena terjadi defect sebanyak 1 unit yang menyebabkan harus mengganti benda yang defect tersebut.

Ikhsan Baharudin, Ahmad Jaka Purwanto, Muchammad Fauzi 


\section{Faktor Waiting}

Waste waiting ini terjadi ketika operator harus menunggu mesin berjalan dengan cycle time yang cukup lama. Walaupun operator sedang mempersiapkan alat potong untuk operasi selanjutnya, jarak waktu antara proses persiapan alat potong dan cycle time cukup jauh sehingga terjadi aktivitas non produktif oleh operator. Waste waiting yang lain adalah ketika operator harus mengukurkan benda yang sudah di proses di setiap operasi kepada bagian $Q A$ untuk pertama kalinya. Ketika proses pengukuran, mesin tidak berjalan untuk menunggu ukuran dan operator menganggur kembali. Hal ini terjadi di setiap selesai pengerjaan di setiap proses operasi untuk pertama kalinya. Proses pengukuran $Q A$ adalah 30 menit per satu kali mengukur. Proses pengukuran oleh $Q A$ harus mengalami antrian, karena setiap inspector $Q A$ menghandel 5 sampai 6 mesin area produksi sehingga jika semua mesin mengukur pada $Q A$, akan terjadi downtime yang lebih lama lagi. Dan hal ini terus berulang untuk setiap operasi, artinya downtime akan terjadi sebanyak 8kali untuk 1 unit benda yang di proses.

\section{Faktor Non-Utilizing Employee}

Waste Non-Utilizing Employee terjadi apabila adanya tenaga kerja yang tidak sedang melakukan pekerjaan sesuai dengan SOP atau melakukan pekerjaan yang tidak added value. Berdasarkan pengamatan langsung dan brainstorming, operator pada area produksi sudah terutilisasi dengan baik sesuai dengan pengetahuan dan kemampuannya masing-masing namun masih terjadi kesalahan komunikasi diantara operator disaat pergantian shift sehingga menyebabkan kesalahan pengertian disaat mengoperasikan mesin dan berujung pada produk yang defect atau tidak sesuai spesifikasi. Shift kerja dibagi menjadi tiga shift dan masing-masing shift memiliki delapan jam kerja dengan tenaga operator sebanyak 7 orang.

\section{Faktor Transportation}

Waste transportation yang terjadi pada proses ini adalah adanya proses pengukuran yang berulang sehingga mengharuskan adanya perpindahan benda dari mesin di area produksi ke area $Q A$ dengan jarak sekitar 20 meter. Setiap operasi selesai di proses, maka benda diharuskan diukurkan, sehingga akan ada 8 kali pengantaran benda dari area produksi ke bagian $Q A$. Begitu pula dari $Q A$ yang mengantarkan kembali benda ke area produksi. Adanya perpindahan benda yang berulang tentunya akan menyita waktu kerja operator maupun inpector QA.

\section{Faktor Inventory}

Inventory merupakan kategori waste berupa penumpukan dan penyimpanan material selama proses produksi berlangsung. Bentuk inventory yang disimpan dapat berupa produk WIP atau finished goods. Waste inventory terjadi di $Q A$ jika terjadi antrian pengukuran dari beberapa mesin. Ruangan $Q A$ yang terbatas dan banyaknya benda yang harus di ukur oleh $Q A$ akan menyebabkan ketidaknyamanan dan kurang leluasanya inspector $Q A$ dalam melakukan pekerjaannya.

\section{Faktor Motion}

Pada proses produksi PT ABC, waste kategori ini muncul karena disebabkan karena adanya proses set up yang berulang, baik itu proses setup mesin dan juga set up alat potong. Adanya proses setup untuk setiap operasi dan setiap benda tentunya merupakan sebuah waste yang harus dibuang. Waste motion juga terjadi ketika operator melakukan proses persiapan alat potong dimana operator perlu mengambil alat potong pada tool management.

\section{Faktor Extra Processing}

Waste ini merupakan proses berlebihan yang seharusnya tidak perlu diperlukan. Karena proses yang berlebihan tersebut maka akan menambah lead time. Waste kategori ini juga merupakan akibat dari beberapa waste sebelumnya, salah satunya adalah defect. Ketika defect terjadi, maka diperlukan proses produksi tambahan baik itu untuk melakukan rework atau membuat produk baru lagi. Salah satu waste yang terjadi adalah diharuskan melakukan pembuatan produk lagi karena adanya 1 unit defect pada operasi No. 45.

Dari hasil identifikasi ke dalam 9 faktor tersebut. Peneliti menganalisa permasalahan waste pada produk $\mathrm{X}$ adalah setiap proses operasi selesai, benda trial untuk produk $\mathrm{X}$ akan dilakukan pengukuran oleh tim $Q A$, dan pengukuran tersebut dilakukan terus berulang hingga operasi terakhir. Selain itu, terdapat antrian dari tim $Q A$ sehingga menimbulkan downtime yang cukup lama, akibatnya lead time produksi akan lebih lama. Usulan perbaikan yang direkomendasikan oleh peneliti adalah supaya pengukuran benda trial oleh tim $Q A$ dilakukan secara sekaligus yaitu satu kali setelah proses produksi dari operasi pertama sampai operasi terakhir telah selesai.

Ikhsan Baharudin, Ahmad Jaka Purwanto, Muchammad Fauzi 


\section{KESIMPULAN DAN SARAN}

Berdasarkan identifikasi dan analisa pemborosan menggunakan 9 Waste (E-Downtime) pada konsep Lean Manufacturing. Penyebab waste pada proses produksi produk $\mathrm{X}$ di $\mathrm{PT} \mathrm{ABC}$ adalah defect, transportation, overproduction, motion, inventory, waiting dan excess processing. Waste tersebut merupakan efek domino dari pekerjaan pengukuran berulang dan juga setup yang berulang seperti yang ditunjukan pada Tabel 3 berikut:

Tabel 3 Aktivitas Penyebab Waste

\begin{tabular}{cl}
\hline \multicolumn{1}{c}{$\begin{array}{c}\text { Aktivitas penyebab } \\
\text { waste }\end{array}$} & Waste yang terjadi \\
\hline Pengukuran Berulang & Waiting \\
& Transportation \\
& Inventory \\
Set Up Berulang & Defect \\
& Overproduction \\
& Excess Processing \\
\hline \hline
\end{tabular}

Rekomendasi perbaikan terhadap waste tersebut yaitu PT ABC supaya memanfaatkan benda trial untuk dijadikan acuan sebelum melakukan pengerjaan ke produk baru dengan menjalankan semua operasi sekaligus sehingga pengukuran yang diperlukan hanya satu kali. Dengan berkurangnya jumlah proses pengukuran maka akan mengurangi waste yang lain seperti transportation dan juga inventory. Selain itu, dengan melakukan pengerjaan sekaligus pada benda trial maka jumlah proses Set $U p$ alat potong juga hanya perlu dilakukan satu kali.

\section{REFERENSI}

Aziza, N., \& Afandi, M. (2018). Analisis Defect Dan Kualitas Produk Writing and Printing Paper Dengan Six Sigma. Teknika: Engineering and Sains Journal, 2(1), 73.

Gaspersz, V. (2006). Continous Cost Reduction Through Lean-Sigma Aproach: Strategi Dramatik Reduksi Biaya dan Pemborosan Menggunakan Pendekatan Lean Sigma. Jakarta Gramedia Pustaka Utama.

Gaspersz, V. (2007). Lean Six Sigma: for Manufacturing and Services Industries. Jakarta Gramedia Pustaka Utama.
Havi, N. F., Lubis, M. Y., \& Yanuar, A. A. (2018). Penerapan Metode 5S Untuk Meminimasi Waste Motion Pada Proses Produksi Kerudung Instan Di Cv . Xyz Dengan Pendekatan Lean Manufacturing. Jurnal Integrasi Sistem Industri, 5(2), 55-62.

Hines, P. \& Taylor, D. (2000) Going Lean. Lean Enterprise Research Centre Cardiff Business School, Abenconway Building, Colum Drive, Cardiff, UK.

Jakfar, A., \& Setiawan, W. E. (2014). Pengurangan Waste Menggunakan. April, 43-53.

Janson B, E. B. J., \& Nurcaya, I. N. (2019). Penerapan Just in Time Untuk Efisensi Biaya Persediaan. E-Jurnal Manajemen Universitas Udayana, 8(3), 1755.

Novitasari, R., \& Iftadi, I. (2020). Analisis Lean Manufacturing untuk Minimasi Waste pada Proses Door PU. Jurnal INTECH Teknik Industri Universitas Serang Raya, 6(1), 65-74.

Pattiapon, M. L., Maitimu, N. E., \& Magdalena, I. (2020). Penerapan Lean Manufacturing Guna Meminimasi Waste Pada Lantai Produksi I (Studi Kasus: UD Filkin). Arika, 14(1), 23-36.

Puspa S., K., Alex Y., A., \& Rendra, M. (2017). Penerapan Lean Manufacturing Untuk Meminimasi Waste Waiting Time Pada Proses Produksi Spring Guide XXX di CV Gradient. Jurnal Rekayasa Sistem \& Industri (JRSI), 4(02), 170-177.

Soenaryo, H., Rispianda, \& Yuniati, Y. (2015). Usulan Meminimasi Waste Pada Proses Produksi Dengan Konsep Lean Manufacturing di $C V$. X. Jurnal Online Institut Teknologi Nasional, 3(2), 92-103.

Ikhsan Baharudin, Ahmad Jaka Purwanto, Muchammad Fauzi 